KREATIF

Jurnal Ilmiah

Prodi Manajemen Universitas Pamulang
ISSN: 2339-0689 (Print), ISSN 2406-8616 (Online)

Volume 7, No 1 Juni 2019, (Halaman 18-28)

Tersedia online di http://openjournal.unpam.ac.id/index.php/kreatif

\title{
ANALISIS PENGARUH LIABILITAS JANGKA PENDEK DAN EKUITAS TERHADAP TOTAL ASET PT NIPPON INDOSARI CORPINDO Tbk
}

\author{
Francisca Sestri Goestjahjanti \\ STIE Insan Pembangunan \\ sestri@ipem.ac.id
}

\begin{abstract}
ABSTRAK
Tujuan dari penelitian ini untuk menganalisis besarnya pengaruh secara parsial dan simultan antara liabilitas jangka pendek dan ekuitas terhadap total aset yang dimiliki PT. Nippon Indosari Corpindo.Tbk.

Penelitian ini menggunakan data sekunder dari tahun 2009 sampai dengan tahun 2017. Regresi linier dan korelasi berganda, merupakan teknik analisis dengan metode eksplanatori riset untuk pengujian hipotesis penelitian.

Hasil penelitian ini berupa kesimpulan yaitu terdapat pengaruh siginifikan, baik secara parsial maupun simultan, antara liabilitas jangka pendek dan ekuitas terhadap total aset PT. Nippon Indosari Corpindo.Tbk.
\end{abstract}

Kata Kunci : Liabilitas jangka pendek, Ekuitas dan Total Aset

\section{ABSTRACT}

The purpose of this study is to analyze the amount of influence partially and simultaneously between current liabilities and equity to the total assets of PT. Nippon Indosari Corpindo Tbk.

This study uses secondary data from 2009 up to 2017. Linear regression and multiple correlation is an analytical technique with an explanatory research method for the hypothesis test of the research.

The results of this research are conclusions of significant effects, both partially and simultaneously, between current liabilities and equity to the total assets of PT. Nippon Indosari Corpindo.Tbk.

Keywords: Current Liabilities, Equity and Total Assets

\section{PENDAHULUAN}

\section{A. Latar Belakang}

Ditengah krisis global yang masih terus berlangsung, pertumbuhan industri pengolahan makanan minuman di Asia terus tumbuh berkembang diatas rata-rata industri lainnya. Pada tahun 2018 Cina masih sebagai market leader dalam penguasaan industri jenis ini, dengan rekor tertinggi. Pendapatan sebesar 636 miliar dolar Amerika Serikat, merupakan penyumbang 11,2 persen total unit yang dipasok ke toko - toko ritel. Menurut Jiang Junxian Presiden Asosiasi Masakan mengatakan, di Cina sektor makanan dan minuman ini memiliki kontribusi sebesar 20,9 persen terhadap pertumbuhan konsumsi selama tahun 2018. (Republika.co.id, 2018).

Penduduk negara Indonesia lebih kurang 265 juta jiwa merupakan pasar yang luas dan menjanjikan prospek bagi dunia usaha yang bergerak dibidang makanan dan minuman. Data Kementerian perindustrian sepanjang tahun 2018 menunjukkan pertumbuhan sebesar 7,91 persen, yang merupakan bisnis kampiun dan menggiurkan. Pertumbuhan tersebut jauh diatas pertumbuhan ekonomi Indonesia, secara nasional berkisar diangka 5,17 persen. (Bisnis.com, 2018) 
Sari Roti merek dagang yang oleh PT. Nippon Indosari Corpindo Tbk, juga mengalami kenaikan kinerja pada tahun terakhir. Perusahaan yang berkantor pusat di Cikarang Jawa Barat ini, melakukan go public dengan menjual saham perdana kepada masyarakat (IPO) di tahun 2010 pada Bursa Efek Indonesia dengan "ROTI"sebagai inisial saham perseroan.

Total Aset yang dimiliki sampai dengan tahun 2017 sebesar 4,559 trilyun menunjukkan fokus bisnis yang profesional. Berbagai penghargaan yang diperoleh selama tahun 2017 adalah Best Companies se Asia, Top 50 perusahaan terbuka dan Direktur Utama yang dijabat oleh bapak Wendy Yap terpilih sebagai Best CEO di Indonesia dan lain-lain (Annual Report PT. NIC Tbk, 2017).

Pada tahun yang sama perseroan juga menambah kuwajiban atau liabilitas jangka pendek yang cukup besar dari bank loan, sehingga liabilitas jangka pendek naik dari 320,5 miliar ke 1,021 trilyun. Hal ini terjadi untuk membayar obligasi (jangka panjang) yang bunganya cukup tinggi.

Ekuitas merupakan modal sendiri yang terus ditingkatkan kesehatannya, terutama untuk memantapkan struktur modal perusahaan. Semakin besar modal sendiri maka makin tinggi ekuitas yang dimiliki perusahaan. PT. Nippon Indosari Corpindo Tbk, memiliki ekuitas yang semakin meningkat tajam pada tahun 2017 sebesar 2,820 trilyun meningkat 95,5\% dari tahun 2016 sebesar 1,442 menunjukkan komposisi modal sendiri diperkokoh untuk mengimbangi hutang bank jangka pendek yang meningkat.

Ditengah manisnya bisnis makanan minimuan yang menjanjikan, perseroan juga menghadapi persaingan usaha dimana ada pemain - pemain rumahan berbentuk home industry yang jumlahnya 60 persen an, lebih besar dari industri roti klas menengah besar di Indonesia. Bahkan roti sandwich merk "Mr. Bread" yang diproduksi oleh Indoroti Prima Cemerlang merupakan pesaing yang bisa menjadi ancaman tersendiri (KONTAN.co.id).

Pertemuan CEO Investment Summit Belanda- RI mengindikasikan, perseroan harus sudah melirik bisnis di negara lain (Kadin Indonesia 2017: 68)

\section{B. Pokok-Pokok Permasalahan}

Melihat uraian pada bab pendahuluan, maka penelitian ini berfokus tetang permasalahan - pemasalahan sebagai berikut :

1. Bagaimana besarnya pengaruh Liabilitas Jangka Pendek $\left(\mathrm{X}_{1}\right)$ terhadap Total Aset (Y) PT. Nippon Indosari Corpindo, Tbk.?

2. Bagaimana besarnya pengaruh Ekuitas $\left(\mathrm{X}_{2}\right)$ terhadap Total Aset (Y) PT. Nippon Indosari Corpindo, Tbk.?

3. Bagaimana besarnya pengaruh Liabilitas Jangka Pendek $\left(\mathrm{X}_{1}\right)$ dan Ekuitas $\left(\mathrm{X}_{2}\right)$ terhadap Total Aset (Y) PT. Nippon Indosari Corpindo, Tbk.?

\section{KAJIAN PUSTAKA}

\section{A. Teori-teori}

Manajemen Keuangan adalah teori dasar yang memayungi penelitian ini, dan teori lain yang terkait diperoleh dari literatur, buku-buku, serta karya ilmiah baik dari perpustakaan maupun media online (internet).

\section{Manajemen Keuangan}

Pengertian tentang Manajemen Keuangan, menjelaskan keterkaitan dengan sebuah kebijakan yang diputuskan untuk bisnis, merupakan pengendalian finansial sehingga investasi yang dikeluarkan perusahaan berjalan efektif. (Mohammad Najib 2015: 30) 
Sehingga Manajemen Keuangan dapat disimpulkan, merupakan salah satu bidang manajemen fungsional dalam perusahaan yang mempelajari pencarian dan penggunaan dana serta pembagian hasil aktivitas suatu perusahaan .

\section{Majanajemen Keuangan dan AKuntansi}

Hubungan Manajemen Keuangan dan Akuntansi, data-data akuntansi merupakan bahan untuk pengambilan keputusan dalam Manajemen Keuangan, termasuk didalamnya laporan keuangan yang disampaikan oleh akuntansi ( Musthafa $2017: 2$ )

Laba Rugi dan Neraca merupakan media yang menyediakan data-data keuangan. Data yang dimaksud adalah Penjualan, beban pengeluaran serta pendapatan yang disajikan dalam laporan Laba Rugi. Sedangkan aset dan komposisi hutang, permodalan suatu perusahaan yang disajikan dalam buku Neraca.

\section{Akuntansi}

Proses mengumpulkan,pengelompokan, serta verifikasi bukti-bukti data sesuai charge of account atau nomer akun masing-masing departemen, dan dibuat laporan keuangan tersaji dalam bentuk Neraca (Balance Sheet) dan Laba Rugi (Income Statement). Laporan tersebut bagi manajemen suatu perusahaan digunakan untuk mengambil keputusan investasi yang menguntungkan di masa mendatang.

Pendapat Arthur. J. Koewn. et. al (1999 : 2), Manajemen Keuangan menunjukan sebuah kebutuhan, kepentingan dan bagaimana cara menciptakan serta menjaga nilai ekonomis atau kesejahteraan yang menjadi fokus perusahaan.

\section{Sumber-sumber dana untuk liabilitas jangka pendeK}

Menurut Mohammad Najib (2015 : 233) beberapa sumber dana untuk kuwajiban jangka pendek / liabilitas jangka pendek adalah :

a. Utang dagang ( trade credit) sebagai sumber dana saat barang diterima, dengan pembayaran kemudian

b. Pinjaman Bank Jangka Pendek dengan jaminan

c. Pinjaman Bank Jangka Pendek tanpa jaminan

d. Letter of credit, surat berharga yang diterbitkan bank yang ditunjuk

e. Commercial paper, surat berharga dijual perusahaan untuk kebutuhan jaangka pendek

f. Factoring, menjual piutang perusahaan kepada Lembaga Keuangan

\section{Ekuitas}

Struktur modal merupakan perimbangan antara jumlah hutang jangka pendek, hutang jangka panjang, saham preferen dan saham biasa. Perbandingan yang dimaksud adalah perbandingan antara modal sendiri dengan modal asing. Kebijakan tersebut merupakan pemilihan antara resiko dan perolehan atau keuntungan yang diharapkan (Musthafa, 2017 : 85). J M Smith dan Fred Kousen (1996:559) menuliskan metode ekuitas dan akuntansi untuk investasi jangka panjang dalam saham biasa, tujuan metode ini menampilkan hakhak yang dimiliki perusahaan investor atas aktiva bersih investee. Sehingga secara periodik perkiraan-perkiraan investasi disesuaikan untuk memperlihatkan perubahan-perubahan pada aktiva bersih investee.

Kesimpulannya bahwa yang dimaksud ekuitas adalah, modal yang dimiliki perseroan berbentuk saham dimiliki company, baik preferen maupun biasa. Saham biasa dan tambahan modal yang disetor penuh, serta ditambah laba yang ditahan dan tidak dibagikan kepada pemegang saham (Garrison, et. al.2001 : 782) 


\section{Total AseT}

Merupakan kumpulan aset-aset perusahaan yang berupa kekayaan lancar terdiri atas kas dan setara bank, piutang dagang, inventori dan biaya dibayar dimuka (prepaid expenses) serta, aktiva tetap meliputi properti dan peralatan bisa berupa mesin-mesin, tanah dan bangunan, yang dimiliki oleh perusahaan (Garrison, et.al. 2001 : 782) Seringkali aset disebut juga sebagai aktiva yang berupa harta, kekayaan yang dimiliki perusahaan merupakan sumber daya yang dikuasai perusahaan sebagai akibat kegiatan ekonomi masa lalu dan mendapatkan laba dikemudian hari (Ardra.Biz, 2018).

\section{B. Kerangka Berfikir Penelitian}

Kerangka berfikir dalam penelitian ini, merupakan hal yang menguraikan hubungan atau korelasi antara variabel independen "Liabilitas Jangka Pendek $\left(\mathrm{X}_{1}\right)$ " dan variabel independen "Ekuitas $\left(\mathrm{X}_{2}\right)$ " baik secara individual maupun bersama-sama terhadap variabel tak bebas "Total Aset (Y)" dalam bentuk kerangka berfikir ialah:

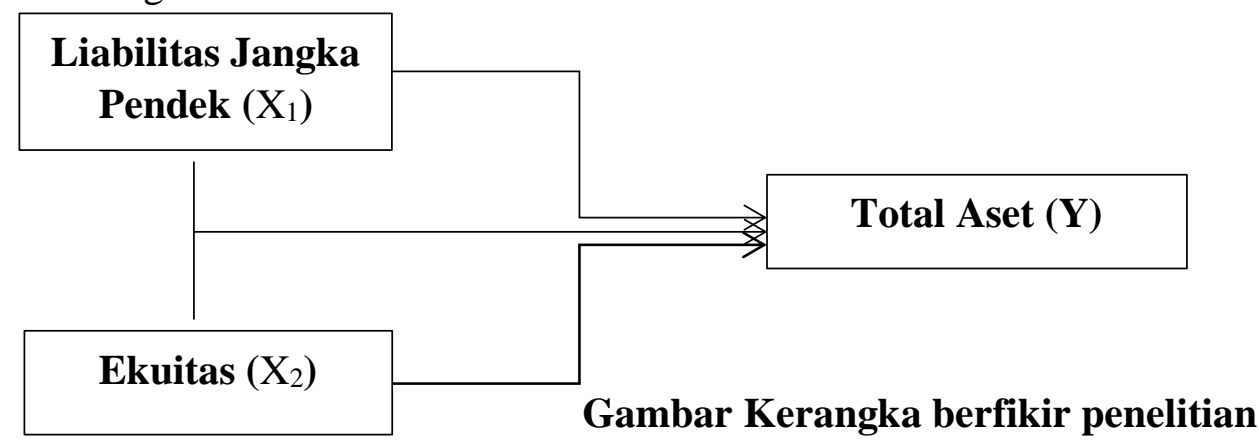

\section{Hipotesis}

Burhan Bungin dalam bukunya (2013: 90), ia berpendapat bahwa hipotesis suatu penelitian masih berupa kesimpulan awal dan belum final, yang masih harus dibuktikan kebenarannya. Maka hipotesis pada penelitian ini ditetapkan untuk dibuktikan dalam analisis selanjutnya, yaitu :

1. Terdapat pengaruh signifikan antara Liabilitas Jangka Pendek $\left(\mathrm{X}_{1}\right)$ terhadap Total Aset PT.Nippon Indosari Corpindo Tbk. (Y).

2. Terdapat pengaruh signifikan antara Ekuitas $\left(\mathrm{X}_{2}\right)$ terhadap Total Aset PT.Nippon Indosari Corpindo Tbk. (Y).

3. Terdapat pengaruh signifikan antara Liabilitas Jangka Pendek $\left(\mathrm{X}_{1}\right)$ dan Ekuitas $\left(\mathrm{X}_{2}\right)$ terhadap Total Aset PT.Nippon Indosari Corpindo Tbk. (Y).

\section{METODE PENELITIAN P}

Penulisan ini menggunakan metode penelitian dengan penjabaran sebagai berikut:

\section{A. Design Penelitian}

Sekaran Uma (2006:158) seorang ahli penelitian mengatakan bahwa eksplanatori riset sebagai studi yang menjelaskan hubungan antar variabel yang digunakan dalam menguji hipotesis.

Sedangkan Sri Mulyono (2017 : 175) dalam bukunya mengatakan, pengujian adalah membuktikan suatu dugaan tentang parameter populasi yang tidak diketahui berdasarkan informasi dan sampel yang diambil dalam populasi tersebut.

Pengambilan data sekunder pada penelitian ini melalui unduh internet Annual Report PT. Nippon Indosari Corpindo Tbk. Data time series selama sembilan tahun, sejak tahun 2009 s/d tahun 2017, dengan $\mathrm{n}=9$, digunakan dalam penelitian ini. 
Waktu yang dibutuhkan untuk pengumpulan data, analisis dan pelaporan hasil penelitian memakan waktu selama 4 (empat) bulan dari bulan Januari 2019 sampai dengan bulan April 2019.

1. Variabel Penelitian dan Batasan Operasional Variabel

Variabel bebas dan tak bebas dalam tulisan ini, diuraikan sebagai berikut :

a) Variabel- variabel independen, yang diberi lambang $\left(\mathrm{X}_{1}\right)$ adalah Liabilitas Jangka Pendek dan $\left(\mathrm{X}_{2}\right)$ adalah Ekuitas

b) Variabel dependen, diberi lambang (Y), adalah Total Aset.

\section{Batasan Operasional Variabel}

Batasan-batasan operasional dalam penelitian ini adalah :

a) Liabilitas jangka pendek

Utang bank, utang usaha, utang pajak dan lain-lain utang jangka pendek yang tercatat dalam Neraca Perseroan diakui sebagai kewajiban lancar (Annual Report PT. Nippon Indosari Corpindo Tbk. 2017: Financial Report hal 2. Diaudit oleh Akuntan Publik Purwantono, Sungkoro \& Surja ).

b) Ekuitas

Komponen modal sendiri yang terdiri dari modal saham,selisih kurs, Laba penjualan saham dan laba korporasi yang ditahan (Annual Report PT. Nippon Indosari Corpindo Tbk. 2017: Financial Report hal. 2. Diaudit oleh Akuntan Publik Purwantono, Sungkoro \& Surja ).

c) Total Aset

Aset lancar berupa : kas dan setara bank, piutang, persediaan, ditambah aset tetap berupa: tanah, bangunan, dll peralatan, aset tak berujud, investasi jangka panjang. ( Annual Report PT. Nippon Indosari Corpindo Tbk. 2017 : Financial Report hal. 1. Diaudit oleh Akuntan Publik Purwantono, Sungkoro \& Surja)

\section{Populasi dan Sampel}

Populasi menurut Husein Umar (2002: 136) populasi yang merupakan kumpulan elemen memiliki karakteristik tertentu yag memiliki kesempatan yang sama untuk dipilih sebagai anggota sampel.Sampel adalah bagian dari populasi itu sendiri.

Populasi yang dimaksud dalam penelitian ini adalah sama dengan sampelnya, yaitu seluruh data liabilitas jangka pendek, ekuitas dan total aset yang tercatat pada neraca perseroan PT. Nippon Indosari Corpindo Tbk.

Pengumpulan data dilakukan dengan teknik sebagai berikut : Teknik perekaman data dalam penelitian ini dengan download internet dari beberapa Annual Report PT. Nippon Indosasi Corpindo Tbk, dengan $\mathrm{n}=9$.

\section{Metode Analisis}

a. Uji Asumsi Klasik

Menurur Gujarati Damodar (2007) agar data yang diteliti tidak bias, maka penelitian ilmiah harus melalui uji asumsi klasik. Suatu cara pengujian agar variabel-variabel penelitian tidak kabur, sehingga hasil penelitian dapat dipakai untuk prediksi keadaan yang akan datang. Uji ini disebut juga Best Linear Unbiased Estimator (Uji BLUE).

b. Uji Korelasi

Uji Korelasi yang diberi simbol (R) merupakan alat analisis untuk mengetahui besarnya hubungan satu atau lebih variabel independen dengan satu variabel dependen. Pada penelitian ini menggunakan analisis korelasi sederhana dan berganda. 
c. Uji Koefisien Determinasi

Merupakan parameter yang menunjukan besarnya pengaruh antara variabel independen terhadap variabel dependen baik secara parsial maupun simultan.

d. Koefisien determinasi biasa diberi lambang ( $\mathrm{Kd}=\mathrm{R}$ Square $)$

Yuyun Wirasamita (2013 :22) selalu menekankan dan menjelaskan, penelitian yang baik apa bila hasil $\mathrm{Kd}>50 \%$ artinya penelitian tersebut dapat digunakan sebagai alat prediksi dimasa yang akan datang.

e. Uji Regresi

Model penelitian ini menggunakan analisis uji regresi linier sederhana yaitu : $\mathrm{X}_{1}$ terhadap $\mathrm{Y}$, dan $\mathrm{X}_{2}$ terhadap $\mathrm{Y}$. Serta menggunakan uji regresi berganda yaitu : $\mathrm{X}_{1}$ dan $\mathrm{X}_{2}$ terhadap $\mathrm{Y}$

\section{ANALISIS DATA}

\section{A. Deskripsi Objek Penelitian}

Pengolahan data sekunder pada penelitian ini mengenai variabel independen liabilitas atau kuwajiban jangka pendek, yang diduga memiliki pengaruh signifikan terhadap total aset. Variabel independen ekuitas diduga memiliki pengaruh signifikan terhadap total aset dan variabel- variabel independen liabilitas jangka pendek dan ekuitas diduga secara bersama-sama berpengaruh signifikan terhadap total aset PT Nippon Indosari Corpindo Tbk. Terlampir data-data variabel yang diteliti selama sembilan tahun sebagai berikut :

Tabel 3

Liabilitas jangka pendek, Ekuitas dan Total Aset Tahun 2009 - 2017

(Ln)

\begin{tabular}{|c|c|c|c|}
\hline Tahun & $\begin{array}{c}\text { LN LIABILITAS } \\
\text { JK.P } \\
\end{array}$ & $\begin{array}{c}\text { LN } \\
\text { EKUITAS }\end{array}$ & LN ASET \\
\hline 2009 & 11,48879567 & 11,91363127 & 12,67132249 \\
\hline 2010 & 11,43646658 & 13,02904649 & 13,25034367 \\
\hline 2011 & 11,90637939 & 13,21118199 & 13,53993741 \\
\hline 2012 & 12,18308852 & 13,40995685 & 14,00194423 \\
\hline 2013 & 12,67669296 & 13,57641241 & 14,41582346 \\
\hline 2014 & 12,6365838 & 13,76798175 & 14,57766795 \\
\hline 2015 & 12,88896745 & 13,98823193 & 14,81110169 \\
\hline 2016 & 12,67764317 & 14,17147151 & 14,88697088 \\
\hline 2017 & 13,84232433 & 14,85228492 & 15,33273969 \\
\hline
\end{tabular}

Sumber : Annual Report PT. Nippon Indosari Corpindo Tbk.(diolah)

Sistem Ln diterapkan agar diperoleh data penelitian yang akurat sebelum dilakukan tahap berikutnya yaitu analisis statistik.

B. Analisi Model 1, $Y=F\left(X_{1}\right)$

SPSS-22 yang digunakan untuk analisis data, menujukan hasil sebagai berikut :

Tabel 4

Korelasi Liabilitas Jangka Pendek (X) dan Total Aktiva (Y)

PT. Nippon Indosari Corpindo Tbk

Model Summary 


\begin{tabular}{|l|c|r|r|r|}
\hline Model & R & R Square & $\begin{array}{c}\text { Adjusted R } \\
\text { Square }\end{array}$ & $\begin{array}{c}\text { Std. Error of } \\
\text { the Estimate }\end{array}$ \\
\hline 1 &, $944^{\mathrm{a}}$ &, 891 &, 875 &, 30657 \\
\hline
\end{tabular}

a. Predictors: (Constant), Liabilitas Jk Pendek (X1)

\section{Uji Korelasi Sederhana}

Hasil perhitungan statistik pada tabel 4, didapat korelasi sederhana Liabilitas Jangka Pendek $\left(\mathrm{X}_{1}\right)$ terhadap Total Aset $(\mathrm{Y})$, sebesar $\mathbf{R = 0 , 9 4 4}$ yang berarti, hubungan $\mathrm{X}_{1}$ dan $\mathrm{Y}$ sangat kuat dan positif

\section{Uji Koefisien Determinsi}

Hasil statistik tabel 4, menunjukkan besarnya Kd. berlambang $\left(\mathrm{R}^{2}\right)=$ 0,891 artinya, variabel Liabilitas Jangka Pendek $\left(\mathrm{X}_{1}\right)$ berpengaruh terhadap Total Aset $(\mathrm{Y})$ sebesar $=\mathbf{8 9 , 1 0} \%$ dan sisanya $10,90 \%$ dipengaruhi faktorfaktor lain yang tidak diteliti.

\section{Uji Regresi}

Tabel 5

\section{Persamaan Regresi $Y=f\left(X_{1}\right)$}

Coefficients $^{\text {a }}$

\begin{tabular}{|c|c|c|c|c|c|c|}
\hline \multirow{2}{*}{\multicolumn{2}{|c|}{ Model }} & \multicolumn{2}{|c|}{$\begin{array}{c}\text { Unstandardized } \\
\text { Coefficients }\end{array}$} & \multirow{2}{*}{$\begin{array}{c}\text { Standardized } \\
\text { Coefficients } \\
\text { Beta }\end{array}$} & \multirow[b]{2}{*}{$l$} & \multirow[b]{2}{*}{ Sig. } \\
\hline & & $\mathrm{B}$ & Std. Error & & & \\
\hline 1 & (Constant) & ,726 & 1,782 & & , 407 & ,696 \\
\hline & $\begin{array}{l}\text { Liabilitas Jk } \\
\text { Pendek (X1) }\end{array}$ & 1,083 & , 143 & ,944 & 7,554 & ,000 \\
\hline
\end{tabular}

a. Dependent Variable: Total Aset (Y)

Ekuasi suatu persamaan : $\mathrm{Y}=\mathrm{a}+\mathrm{b} \mathrm{X}_{1}+\varepsilon$

$$
\begin{array}{ll}
\mathrm{Y}=\text { Total Aset } & \mathrm{a}=\mathrm{C} \text { suatu konstante } \\
\mathrm{X}_{1}=\text { Liabilitas Jangka Pendek } & \varepsilon=\text { Error standard }
\end{array}
$$

Hasil analisis regresi diperoleh $\mathbf{Y}^{\wedge}=\mathbf{0 , 7 2 6}+\mathbf{1 , 0 8 3} \mathrm{X}_{\mathbf{1}}$

Berdasarkan tabel 5, menunjukkan persamaan regresi tersebut antara variabel bebas dan variabel tak bebas berpengaruh postitif, yaitu nilai Konstanta (C) dan Perubahan Liabilitas jangka pendek $\left(\mathrm{X}_{1}\right)$ memiliki parameter searah terhadap perubahan Total Asetnya $\left(\mathrm{Y}^{\wedge}\right)$.

Persamaan regresi tabel 5 dapat diinterpretasikan, apabila diketahui Konstanta $(\mathrm{C})=0$, maka prediksi nilai Total Aset $\left(\mathrm{Y}^{\wedge}\right)$ menjadi $=1,083 \mathrm{x}$ Liabilitas jangka pendek $\left(\mathrm{X}_{1}\right)$. Dan apabila Liabilitas jangka pendek $\left(\mathrm{X}_{1}\right)=0$, maka prediksi Total Asetnya $\left(\mathrm{Y}^{\wedge}\right)=0,726$ senilai konstanta tersebut. Variabel -variabel lain diasumsikan seteris paribus.

\section{Uji t (Uji hipotesis partial)}

Uji t merupakan uji hipotesis parsial,dari hasil analisis menggunakan 2Tailled adalah: Diketahui $\mathrm{n}=9, \mathrm{k}=1, \alpha=0,05$, maka $\mathrm{t}$ tabel $(\mathrm{n}-\mathrm{k})=2,306$. Berdasarkan tabel 5, diketahui $\mathrm{t}_{\text {hitung }}=7,554>\mathrm{t}_{\text {tabel }}=2,306$

Tingkat signifikansi Prob. menunjukkan angka $=0,000$ lebih kecil dari p-Value

$\alpha=0,05$. Sehingga hipotesis model 1 ini, menyatakan Ho ditolak Ha diterima, maka terdapat pengaruh signifikan dan positif, antara variabel Liabilitas jangka pendek $\left(\mathrm{X}_{1}\right)$ terhadap Total Aset $(\mathrm{Y})$. 
C. Analisis Model 2, $Y=\mathbf{f}\left(\mathbf{X}_{2}\right)$

Analisis data pada riset ini dengan program statistic SPSS-22, memaparkan hasil sebagai berikut :

Tabel 6

Korelasi Ekuitas $\left(\mathbf{X}_{2}\right)$ dan Total Aset (Y)

Model Summary

\begin{tabular}{|l|r|r|r|r|}
\hline Model & R & R Square & $\begin{array}{c}\text { Adjusted R } \\
\text { Square }\end{array}$ & $\begin{array}{r}\text { Std. Error of } \\
\text { the Estimate }\end{array}$ \\
\hline 1 &, $965^{\mathrm{a}}$ &, 931 &, 921 &, 24366 \\
\hline
\end{tabular}

a. Predictors: (Constant), Ekuitas ( $\mathrm{X}_{2}$ )

\section{Uji Korelasi sederhan}

Tabel 6 diatas, menunjukkan hasil analisis uji korelasi sederhana $\mathbf{R}=\mathbf{0 , 9 6 5}$ menunjukkan hubungan sangat kuat dan positif antara Korelasi Ekuitas $\left(\mathrm{X}_{2}\right)$ dan Total Aset (Y).

2. Uji Koefisien Determinasi

Tabel 6 diatas, menunjukkan hasil analisis koef. determinasi dengan lambang ( $\left.\mathrm{R}^{2}\right)=0,931$, angka ini menjelaskan secara partial pengaruh antara variabel Ekuitas $\left(\mathrm{X}_{2}\right)$ terhadap Total Aset $(\mathrm{Y})$ sebesar $=\mathbf{9 3 , 1 0} \%$ dan, sisanya $6,90 \%$ dipengaruhi faktor-faktor lain diluar model yang diteliti.

3. Uji Regresi Linier Sederhana

Tabel 7

Persamaan Regresi $\mathbf{Y}=\mathbf{f}\left(\mathbf{X}_{2}\right)$

Coefficients $^{\text {a }}$

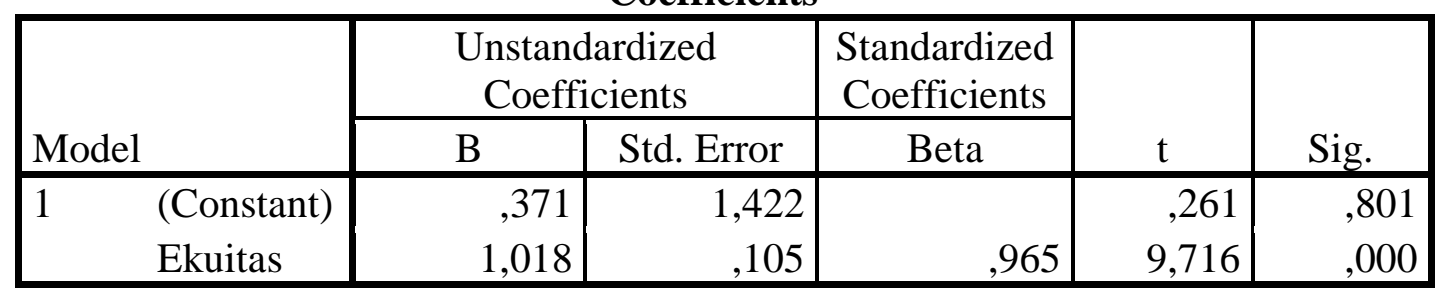

a. Dependent Variable: Total Aset (Y)

Tabel 7, menunjukkan hasil analisis statistik, didapat persamaan regresi linier sederhana sebagai berikut:

Persamaan regresi : $Y=a+b_{2} X_{2}+\varepsilon$

Kertangan

Variabel $\mathrm{Y}=$ Total Aset

Variabel $\mathrm{X}_{2}=$ Ekuitas

$\mathrm{a}=\mathrm{C}($ Constant $)$

Prediksi $Y^{\wedge}=\mathbf{0 , 3 7 1}+\mathbf{1 , 0 1 8} \mathbf{X}_{\mathbf{2}}$

$\varepsilon=$ Standar penyimpangan

Persamaan regresi tersebut diatas menunjukkan adanya pengaruh konstanta postif terhadap prediksi Total Aset $\left(\mathrm{Y}^{\wedge}\right)$, dan pengaruh positif Ekuitas $\left(\mathrm{X}_{2}\right)$ terhadap prediksi $\left(\mathrm{Y}^{\wedge}\right)$, memiliki hubungan parameter searah.

Model 2 ini dapat diinterpretasikan yaitu, nilai a $=0$, maka nilai Total Aset diperkirakan menjadi $\left(\mathrm{Y}^{\wedge}\right)=1,018 \mathrm{x}\left(\mathrm{X}_{2}\right)$. Sedangkan apabila variabel Ekuitas $\left(\mathrm{X}_{2}\right)=$ nol, maka perdiksi terhadap $\left(\mathrm{Y}^{\wedge}\right)$ adalah sebesar $=0,371$ sama dengan konstantanya. Variabel-variabel lain diasumsikan seteris paribus.

4. Uji t (Uji hipotesis partial) 
Uji t, metode $2 \mathrm{~T}$-tille digunakan dalam uji ini menunjukan hasil sebagai berikut : Diketahui $\mathrm{n}=9, \mathrm{k}=1$, alpha $=0,05, \mathrm{t}$ tabel diperoleh angka $=2,306$. Tabel 7 menunjukkan $\mathrm{t}_{\text {hitung }}=9,716$. Karena $\mathrm{t}_{\text {hitung }}>\mathrm{t}_{\text {tabel }}$.

Dan tingkat Signifikansi Prob. menunjukkan angka $=0,000<$ dari $\mathrm{p}$ Value dengan tingkat kesalahan $=0,05$, maka pengaruh signifikan. Model 2 dengan hipotesis, Ho ditolak dan Ha diterima, yaitu terbukti ada pengaruh signifikan serta positif antara variabel bebas Ekuitas $\left(\mathrm{X}_{2}\right)$ terhadap variabel terikat Total Aset (Y).

D. Analisis Model 3, $Y=f\left(X_{1}, X_{2}\right)$

Hasil analisisi statistik menggunakan program SPSS-22 menujukan hasil sebagai berikut

\section{Tabel 8}

Korelasi Berganda Var. $X_{1}$, dan Var. $X_{2}$ Terhadap Var. Y Model Summary Hasil SPSS-22

\begin{tabular}{|l|c|r|r|r|}
\hline Model & R & R Square & $\begin{array}{c}\text { Adjusted R } \\
\text { Square }\end{array}$ & $\begin{array}{c}\text { Std. Error of } \\
\text { the Estimate }\end{array}$ \\
\hline 1 &, $978^{\mathrm{a}}$ &, 957 &, 943 &, 20730 \\
\hline
\end{tabular}

a. Predictors: (Constant), X1 (Liabilitas Jk pendek), X2 (Ekuitas)

\section{Uji Korelasi berganda}

Hasil perhitungan statistik pada tabel 8, didapat korelasi berganda Liabilitas Jangka Pendek $\left(\mathrm{X}_{1}\right)$ dan Ekuitas $\left(\mathrm{X}_{2}\right)$ terhadap Total Aset $(\mathrm{Y})$, sebesar $\mathbf{R}=$ $\mathbf{0 , 9 7 8}$ yang berarti, hubungan $X_{1}$ dan $X_{2}$ terhadap $Y$ sangat kuat dan positif

\section{Uji Koefisien Determinsi}

Hasil perhitungan statistik tabel $8,\left(\mathrm{R}^{2}\right)$ merupakan besaran pengaruh variabelvariabel bebas terhadap variabel takbebas, diperoleh hasil $=0,957$, menjelaskan secara simultan antara Liabilitas Jangka Pendek $\left(\mathrm{X}_{1}\right)$ dan Ekuitas $\left(\mathrm{X}_{2}\right)$ terhadap Total Aset $(\mathrm{Y})$ pengaruhnya $=\mathbf{9 5 , 7 0} \%$ dan sisanya 4,30 \% dipengaruhi faktorfaktor lain yang tidak diteliti.

\section{Uji Regresi Berganda}

\section{Tabel 9}

Persamaan Regresi $Y=\mathbf{f}\left(\mathbf{X}_{1}, \mathbf{X}_{2}\right)$

Coefficients $^{\mathrm{a}}$

\begin{tabular}{|c|c|c|c|c|c|c|}
\hline \multirow{2}{*}{\multicolumn{2}{|c|}{ Model }} & \multicolumn{2}{|c|}{$\begin{array}{c}\text { Unstandardized } \\
\text { Coefficients } \\
\end{array}$} & \multirow{2}{*}{$\begin{array}{l}\text { Standardized } \\
\text { Coefficients } \\
\text { Beta }\end{array}$} & \multirow[b]{2}{*}{$\mathrm{t}$} & \multirow[b]{2}{*}{ Sig. } \\
\hline & & $\mathrm{B}$ & Std. Error & & & \\
\hline \multirow[t]{4}{*}{1} & (Constant) &,- 116 & 1,236 & &,- 094 & ,928 \\
\hline & $\begin{array}{l}\text { Ekuitas } \\
\text { (X2) }\end{array}$ & ,649 & ,213 & 615 & 3,051 & ,022 \\
\hline & Hutang Jk & & & & & \\
\hline & $\begin{array}{l}\text { Pendek } \\
\text { (X1) }\end{array}$ & 443 & ,231 & ,386 & 1,916 & ,104 \\
\hline
\end{tabular}

a. Dependent Variable: Total Aset (Y)

Persamaan Model regresi berganda $Y=a+b_{1} X_{1}+b_{2} X_{2}+\varepsilon$

Keterangan model $\mathrm{Y}=$ Total Aset $\mathrm{a}=\mathrm{C}$ (konstante)

$\mathrm{X}_{1}=$ Liabilitas Jangka Pendek $\quad \varepsilon=$ Standar eror

$\mathrm{X}_{2}=$ Ekuitas 
Persamaan untuk prediksi:

\section{$Y^{\wedge}=-0,116+0,649 X_{1}+0,443 X$}

Berdasarkan tabel 9, menunjukkan persamaan regresi tersebut antara variabelvaribel bebas dan variabel tak bebas berpengaruh postitif, yaitu Perubahan Liabilitas jangka pendek $\left(\mathrm{X}_{1}\right)$ dan Ekuitas $\left(\mathrm{X}_{2}\right)$ memiliki parameter searah terhadap prediksi Total Asetnya $\left(\mathrm{Y}^{\wedge}\right)$. Sedangkan Konstanta tidak searah dengan prediksi perubahan Total Asetnya $\left(\mathrm{Y}^{\wedge}\right)$

Persamaan regresi tabel 9 dapat diinterpretasikan, apabila diketahui Konstanta $(\mathrm{C})=0$, maka prediksi nilai Total Aset $\left(\mathrm{Y}^{\wedge}\right)$ menjadi $=0,649 \mathrm{x}$ Liabilitas jangka pendek $\left(\mathrm{X}_{1}\right)+0,443 \mathrm{x}$ Ekuitas $\left(\mathrm{X}_{2}\right)$. Apabila Hutang jangka pendek $\left(\mathrm{X}_{1}\right)=0$, dan Ekuitas $\left(\mathrm{X}_{2}\right)=0$, maka prediksi Total Asetnya $\left(\mathrm{Y}^{\wedge}\right)=-0116$ menurun senilai konstanta tersebut. Dengan ketentuan Variabel -variabel lain Diasumsikan Seteris Paribus.

\section{E. Uji F (Alat Pengujian Hipotesis Simultan)}

Tabel 10

Uji Kesimpulan sementara Simultan

$X_{1}$ dan $X_{2}$ Terhadap $Y$

ANOVA $^{a}$

\begin{tabular}{|ll|r|r|r|r|r|}
\hline \multicolumn{2}{|l|}{ Model } & \multicolumn{1}{|c|}{$\begin{array}{c}\text { Sum of } \\
\text { Squares }\end{array}$} & df & Mean Square & F & Sig. \\
\hline 1 & Regression & 5,763 & 2 & 2,881 & 67,049 &, $000^{\mathrm{b}}$ \\
& Residual &, 258 & 6 &, 043 & & \\
& Total & 6,020 & 8 & & & \\
\hline
\end{tabular}

a. Dependent Variable: Total Aset

b. Predictors: (Constant), Liabilitas Jk Pendek, Ekuitas

Melalui perhitungan statistik uji hipotesis secara bersama-sama adalah:

Diketahui $\mathrm{n}=9, \mathrm{k}=1, \alpha=0,05$, maka $\mathrm{F}$ tabel $=4,387$. Berdasarkan tabel 10 diatas, diperoleh hasil $\mathrm{F}_{\text {hitung }}=67,049>\mathrm{t}_{\text {tabel }}=4,387$. Tingkat signifikansi Prob. menunjukkan angka $=0,000<$ dari p Value Alpha 0,05 , menunjukkan pengaruh secara simultan signifikan.

Maka hipotesis model 3, Ho ditolak Ha diterima, yaitu terdapat pengaruh positif,signifikan antara variabel Liabilitas jangka pendek $\left(\mathrm{X}_{1}\right)$ dan Ekuitas $\left(\mathrm{X}_{2}\right)$ terhadap Total Aset (Y).

\section{KESIMPULAN}

Kesimpulan penelitian ini setelah memperhatikan analisis diatas adalah :

1. Terdapat pengaruh signifikan antara Liabilitas Jangka Pendek $\left(\mathrm{X}_{1}\right)$ terhadap Total Aset (Y) PT. PT. Nippon Indosari Corpindo Tbk. Besarnya pengaruh yaitu $\mathbf{8 9 , 1 0} \%$, sisanya $10,90 \%$ dipengaruhi faktor-faktor lain yang tidak diteliti

2. Terdapat pengaruh signifikan antara Ekuitas $\left(\mathrm{X}_{2}\right)$ terhadap Total Aset (Y) PT. PT. Nippon Indosari Corpindo Tbk.Besarnya pengaruh sebesar 93,10 \% dan, sisanya $6,90 \%$ dipengaruhi faktor-faktor lain yang tidak diteliti.

3. Terdapat pengaruh signifikan antara Liabilitas Jangka Pendek $\left(\mathrm{X}_{1}\right)$ dan Ekuitas $\left(\mathrm{X}_{2}\right)$ terhadap Total Aset (Y) PT. Nippon Indosari Corpindo Tbk.Besarnya pengaruh sebesar 95,70 \% dan sisanya 4,30\% dipengaruhi faktor-faktor lain yang tidak diteliti. 


\section{SARAN}

Dalam penelitian ini penulis memberikan saran terkait hasil penelitian diantaranya:

1. Liabilitas atau Kuwajiban jangka pendek PT. Nippon Indosari Corpindo Tbk. makin meningkat khususnya hutang bank, karena pemindahan hutang obligasi jangka panjang ke Liabilitas jangka pendek harus dilakukan dengan cermat.

2. Ekuitas PT. Nippon Indosari Corpindo Tbk. harus dimaintenance dengan perimbangan lebih besar dibanding total hutang.

3. Total Aset PT. Nippon Indosari Corpindo Tbk. yang terus meningkat perlu diikuti ekspansi usaha ke luar negeri, dan menjadi bapak asuh para perusahan home industry yang masih mendominir pasar di Indonesia.

\section{DAFTAR PUSTAKA}

Arthur J. Koewn. et.al., (1999). Dasar-dasar Manajemen Keuanga. Jakarta: Salemba Empat.

Financial Report PT. Nippon Indosari Corpindo Tbk. (2009-2017) diaudit oleh Kantor Akuntan Publik.

Burhan B, (2013). Metodologi Penelitian Sosial dan Ekonomi. Jakarta: Penerbit Kencana Prenada Media Group.

Garrison dan Noreen. (2001). Akuntansi Manajerial 2, Jakarta: Salemba Empat, diterjemahkan oleh A. Totok Budisantoso.

Gujarati Damodar. (2007). Dasar-dasar Ekonometrika, Jakarta: Penerbit Erlangga.

Husein Umar. (2002). Metode Riset Bisnis. Jakarta: Gramedia Pustaka Utama.

Jay M Smith \& K Fred Kousen. (1996). Akuntansi Intermediate, Jilid I edisi 9. Jakarta: Erlangga.

KADIN Indonesia. (2017). Membangun dan Memeratakan Ekonomi. Jakarta : Majalah Kadin Indonesia.

Musthafa. (2017). Manajemen Keuangan. Yogyakarta: Andi.

Muhammad Najib,. (2015). Manajemen Keuangan. Bnadung : CV. Pustaka Setia.

Rebuk Tingkat Nasional. (2017). $R$ \#3 Tentang Penataan Ekonomi Industri Perdagangan. PRJ Jakara: Pelaku Usaha Indonesia.

Sekaran. (2010). Metode- Metode Riset untuk Bisnis. Diterjemahkan oleh Kwan Men Yon, Jakarta: Penerbit Salemba Empat.

Yuyun Wirasasmita.(2013). Buku Ajar Metode Penelitian, Jakarta: Fakultas Ekonomi,Universitas Borobudur.

\section{Internet}

Anit Dewi Lestari. (2010). Pengaruh Struktur Aktiva Pertumbuhan dan Likuiditas terhadap Struktur Modal Perusahaan. Vol 6, No 2 (2010) Fakultas Bisnis,UKDW.. journalfb.ukdw.ac.id/index.php/jrak/article/view/40

Ardra. Biz., (2018). Ekonomi Akuntansi. Media online. https://ardra.biz/ekonomi/ekonomi-akuntansi/pengertian-aktiva-lancar-tetaplaporan-keuangan/.

Bisnis. Com. (2018). Industri Mamin sektor kampiun. Berita online. https://ekonomi.bisnis.com/read/20190219/257/890539/industri-makanandanminuman-jadi-sektor-kampiun

Bisnis.com. (2018). Nippon Indosari lunasi obligasi. Berita online https://market.bisnis.com/read/20180712/192/815949/nippon-indosari rotilunasiobligasi-rp500-miliar 